\title{
Mitigating demand risk of durable goods in online retailing
}

\begin{abstract}
Purpose - An uncertain product demand in online retailing leads to loss of opportunity cost and customer dissatisfaction due to instances of product unavailability. On the other hand, when eretailers store excessive inventory of durable goods to fulfil uncertain demand, it results in significant inventory holding and obsolescence cost. In view of such overstocking/understocking situations, this study attempts to mitigate online demand risk by exploring novel e-retailing approaches considering the trade-offs between opportunity cost/customer dissatisfaction and inventory holding/obsolescence cost.
\end{abstract}

Design/methodology/approach - Four e-retailing approaches are introduced to mitigate uncertain demand and minimize the economic losses to e-retailer. Using three months purchased history data of online consumers for durable goods, four proposed approaches are tested by developing product attribute-based algorithm to calculate the economic loss to the e-retailer.

Findings - Mixed e-retailing method of selling unavailable products from collaborative e-retail partner and alternative product's suggestion from own e-retailing method is found to be best for mitigating uncertain demand as well as limiting customer dis-satisfaction.

Research limitations/implications - A limited numbers of risk factor have been considered in this study. In the future, others risk factors like fraudulent order of high demand products, long delivery time window risk, damage and return risk of popular products can be incorporated and handled to reduce the economic loss.

Practical implications - The analysis can minimize the economic losses to a e-retailer and also can maximize the profit of collaborative e-retailing partner.

Originality/value - The study proposes a retailer to retailer collaboration approach without sharing the forecasted products' demand information.

Keywords: Demand risk; Online retailing; Demand management; e-retailing; e-business 


\section{Introduction}

In the world of e-commerce, consumers spend their valuable time and energy looking for preferred products online. However, there are typically several instances of consumer's dissatisfaction owing to a number of reasons viz. high price, long delivery time window, and unavailability of products etc. (Lombart and Louis 2012; Jang, Prasad, and Ratchford 2017; Koos and Shaikh 2019). An out of stock product is one such specific case that is typically an unmitigated outcome of different types of risks including demand risk, inventory risk, and purchasing risk inherent in the system (Dadouchi and Agard 2018; Sodhi 2005; Sarangi and Srivatsan 2009). E-retailers face difficulties while dealing with different types of demand risks present in the system namely demand shortfall, latent demand, seasonal demand, excess demand and demand volatility etc. (Alonso-Ayuso et al. 2018; Lachapelle 2018; Ehrenthal et al. 2014; Andersson et al. 2014; Papanagnou and Matthews-Amune 2018). It has been observed that the purchasing risk associated with consumers significantly impact the online price dispersion (Zhuang et al. 2018; Zhang and Wang 2017).

Demand shortfall often occurs with new products as predicting the demand of new products is relatively challenging for the e-retailers. This is particularly evident in case of retailers operating in fashion apparel as they face difficulties in choosing right set of products to enlist on the website for the upcoming sales season due to the uncertain demand in the fashion industry (Alonso-Ayuso et al. 2018; Choi 2018). In this regards, Choi (2018) categorized new product selection problem into two periods based on the known and unknown forecasted demand and proposed a novel markdown sponsor tariff (MST) model in context of two-level supply chain coordination. Furthermore, Afrin et al. (2018) integrated demand differentiation index (DDI) with modified exponential weighted moving average (DDI-EWMA) method for the automobile industry to predict the demand of a long life-cycle product. Likewise, latent demand risk occurs due to products' expensive price and distribution issues (Lachapelle 2018).

Retailers typically rely on the demand forecasting as a means to mitigate the risks associated with product demand. However, when such forecasting does not capture the demand risk effectively, the results are often catastrophic. One such example of resulting economic losses due to ineffective demand planning was related to Walmart; wherein, the company lost around $\$ 3$ Billion in 2013 owing to out of stock merchandise (Forbes 2014). It is estimated that the retailers 
miss out on nearly $\$ 1$ Trillion of sales due to lack of clarity on customers buying preferences (RetailDive 2018). The facts presented above aptly illustrate that role effective demand planning for minimizing economic losses to retailers and other e-commerce players.

It is widely known both in industry and academic domain, that many sellers including airline industry follow markdown and markup price optimization policy (Cosgun et al. 2017; Nagare and Dutta 2018; Chung et al. 2011) for revenue management problem with uncertain customer demand. In particular, Ni et al. (2015) developed novel markdown and markup dynamic pricing policies based on competitive analysis of demand uncertainty. Considering seasonality in demand forecasting models significantly improves inventory management of seasonal products (Ehrenthal et al. 2014). Many firms expect excess demand owing to the products' brand image and product prices (Zhang et al. 2018). Therefore, flash sale (FS) - a prominent e-commerce marketing technique is rolled out for a limited time accompanying by discounted offers in specific segments. This in turn has a favorable impact on the normal sales period. Zhang et al. (2018) have observed that word-of-mouth (WOM) due to the flash sale and price discrimination positively influence the demand in the normal period. However, the excess demand creates difficulties for supplier to secure parts, materials, and e-retailers to manage inventory. In such case of demand volatility, rise and fall in demand are often rapid. This can lead to firms investing in expensive capacity expansions only to see demand collapse and its supply chain flushed with excess inventory (Papanagnou and Matthews-Amune 2018).

In the extant literature, scholars have proposed methods to improve the accuracy of demand forecasting, introduce dynamic pricing policies based on products' demand, and analyze the value of accounting for demand seasonality in inventory control etc. Previous researchers have considered various demand risk scenarios in their models aimed at better policy formulation considering demand shortfall, latent demand, seasonal demand, excess demand and demand volatility etc. However, research frameworks aimed at minimization of economic losses, customer dissatisfaction costs, obsolescence risk costs, inventory cost due to uncertain product demand, is lacking in extant studies particularly for durable goods. Loss of opportunity cost and customer dissatisfaction cost occurs due to insufficient products' availability. On the other hand, a high amount of inventory cost and obsolescence risk costs relates to storing extra durable goods in the inventory for long period. Customers dissatisfaction also occurs owing to a e-retailer not having the desired products in their offering (Koos and Shaikh 2019). Dadouchi and Agard (2018) argued 
for shifting of demand based on mapping of limited inventory to valued customers, and adequate inventory to other customers. In traditional multi-echelon supply chain models, information pertaining to single quantity order flows from retailer to wholesaler to distributor to factory and finally to supplier, while the product flows in the opposite direction (Costantino et al. 2016). Information is typically exchanged so that customer demand can be shared with all concerned entities within the supply chain (Parsa et al. 2017; Wang and Disney 2016). Recently, Shaban et al. (2019) proposed a collaboration model (IS-OUT) for ordering mechanism of the classical orderup-to policy for multi-echelon supply chains wherein each supply chain echelon can place orders such that demand forecast and product availability is taken into account to adjust the inventory position. Typically, each e-retailing ecosystem has different set of suppliers, wholesalers, factories and distributors. Thus, collaboration between e-retailers further can mitigate the uncertainty associated with product demand. However, to the best of authors' knowledge, research considering the collaboration amongst e-retailers and assessing the impact of different methods of e-retailing on the e-retailer's economic loss in presence of the demand uncertainties is missing. It might be counterproductive for e-retailers to share demand information related to the products of interest, since many of e-retailers compete amongst themselves. Thus, a win-win model can be developed that can incentivise them to collaborate; such that a retailer can sell their products through the dominant e-retailer using the latter's online channel. In such case, the less influential e-retailer can sell their products, while the dominant e-retailer can further their online footprint (Nina et al. 2020).

A product's intrinsic appeal to the customer can influence the sale. In this research, attribute level demand forecasting model is utilized to forecast demand of a durable product. A case example of digital camera is considered. In the context of product lines, customers typically see a product as an amalgamation of a number of product attributes, such that purchase probability of a product is contingent upon the overall utility associated with that product (Goswami et al., 2017). This utility in turn is a function of various product attribute levels of constituent product attribute (for example for attribute "charging time" of a battery, the various attribute levels can be 60 minutes, 120 minutes, 240 minutes). For a typical digital camera, various product attribute could be "charging time", "battery life", "optical zoom" and several others. Extant research studies have modeled the product sales (within a market segment) to be a function of associated product 
attributes and their corresponding levels (Kuzmanovic et al. 2012 and Yu et al. 2017). In line with these arguments, we have adopted attribute-level demand forecasting within this study.

Extant studies have reported several mechanisms through which e-retailers offer their products in the market space. Perhaps the most common method relates to the mechanism, wherein a traditional e-retailer stores extra quantities of products, in the anticipation of sales based on the demand forecast. In this retailer assorted planning process, what products to stock and how much to stock is an important consideration to best manage the excess inventory (Mantrala 2009, Kok et al. 2007; Koos et al. 2019). At times, when the desired products are not available with the e-retailer, consumers are also provided with recommendations related to alternative products, that they can purchase (Ashton et al. 2020). In this context, the role of the recommendation system is to reduce the instances of revenue loss (due to lost customers) in such a way that customers can analyze large number of user reviews extracted dynamically from several top e-commerce websites (Kiran et al. 2017; Bag et al. 2019). In case, the desired products are unavailable on the e-retailer's website, the e-retailer can partner with other e-retailer(s) to fulfill the consumers' requirements. Important consideration in such collaboration between two e-retailers is richness of transactional data regarding suppliers' sales, inventory, credits, and interoperability of e-commerce platforms (Nina et al. 2020). In line with above literature, in this paper, four different e-retailing scenarios have been considered for evaluating the economic loss of the concerned e-tailers. These four scenarios correspond to: a) Traditional e-retailing method by storing extra product's quantity; b) Alternative products suggestion using own e-retailing method, c) Selling unavailable products by relying on collaborative e-retailer partner, d) Mixed method of selling unavailable products from collaborative partner and alternative product's suggestion from own e-retailing method. The purpose of this study is to minimize the demand risk and identify which e-retailing method performs well in terms of minimization of economic loss.

The remainder of the paper is arranged as follows. Section 2 presents the state-of-art literature review. Research methodology and framework for managing uncertain demand in eretailing are described in section 3 and 4, respectively. Settings of this analysis are presented in section 5. Results and discussion for this study have been captured in section 6. Furthermore, findings and inferences from this study have been shown in section 7. Finally, articles conclude in section 8 by presenting conclusions and pathways for future research. 


\section{Literature review}

This section presents the literature on various challenges faced by the e-retailer, including risks related to the demand forecasting. The research problem under consideration in this research draws its motivation from four broad domains viz. a) modelling of demand risk; b) customers' purchase decisions; c) economic loss modelling; d) collaboration.

\subsection{Demand risk and economic loss}

Demand risk is predicated upon the potential loss due to gaps between forecasted demand and actual demand. Several factors affect product demand in e-retailing such as online promotions, eservices by other online sellers, and customer behaviour (Shu, Wu, and Chu 2017; Ma et al. 2018; Xu, Munson, and Zeng 2017; Xu, Zeng, and He 2017). Furthermore, when e-retailers disclose the inventory level of particular products, it does influence consumers' purchasing behavior in purchasing such products online (Aydinliyimet al. 2017; He and Oppewal 2018). Understanding the influence of offline social interactions in online shopping benefits e-retailers to mitigate the demand risk (Kim et al. 2017; Martin, Mortimer, and Andrews 2015; Hong 2015). It is common for decisions related to capital investment, revenue management, and marketing etc. to be executed based on demand forecasts (Mukhopadhyay et al. 2007). Demand risk has been mitigated in several ways in the literature including efficient network design and information sharing amongst sales and marketing and operations (Sarangi and Srivatsan 2009). Linear programming, procurement decision models, and online product reviews have often been used in the extant studies to mitigate the demand/inventory risk and maximize the profit of electronics, food and return-freight insurance companies (Shu et al. 2017; Sodhi 2005; Shu et al. 2017; Geng et al. 2017).

\subsection{Purchase decisions and demand risks}

Consumers' purchase intention and affinity towards particular distribution channel, products or services vary based on associated characteristics and risk factors (i.e. social risk, channel risk and transaction risk) present in the system (Zhu, Kowatthanakul, and Satanasavapak 2019; OseiFrimpong 2019; Gutiérrez, Izquierdo, and Cabezudo 2010). Social risk is closely related to involvement towards the online channel which gets affected by buyer profiles and their 
transactions (Antoniadis, Paltsoglou, and Patoulidis 2019; Pantano, Giglio, and Dennis 2018; Gutiérrez, Izquierdo, and Cabezudo 2010). The factors related to product information, product involvement, product price, and word-of-mouth have positive impact on the consumer's purchase willingness (Lee et al. 2017). An uncertain product demand of durable goods is typically source of various types of demand risks in e-retailers. Controlling risk factors associated with uncertain demand is challenging particularly in the contemporary digital era. Manufacturing and supplying durable goods in a shorter time is difficult and costly considering demand uncertainties. Product unavailability/shortages are often accompanied by costs related to customer dissatisfaction, lost opportunity, long purchasing lead time. On the other hand, storing extra durable goods in inventory is often associated with high inventory cost, obsolesce risk cost and locked capital.

\subsection{Mitigation of demand risk considering collaboration}

Mitigation of demand risk of durable goods considering attribute level consumer choices has significant support from the extant research literature. Bronnenberg et al. (2016) have proposed an attribute level consumer's search pattern analysis for durable goods. Further, Bag et al. (2019) incorporated the analysis of consumer review data in the purchase decisions and developed a predictive model to identify the consumer purchase intentions. Further, extensive research has been performed in the literature for coordination/collaboration in multi-echelon supply chains (Chatfield et al. 2004; Costantino et al. 2014; Costantino et al. 2015; Parsa et al. 2017; Shaban et al. 2019). In addition, various information sharing based collaboration methods have also been developed in the multi-echelon supply chains to mitigate the bullwhip effect in supply chains (Wang and Disney 2016; Zarandi and Moghadam 2017; Costantino et al. 2013).

However, mitigating the demand uncertainty for products considering accompanying product attributes of durable goods have not been investigated in the literature sufficiently. However, limited studies have been performed when e-retailers collaborate amongst themselves when uncertain demand need to be mitigated considering the associated risks. The study carried out by Bell et al., (2018) underscored the fact that engagement between online-first retailers (as well as traditional retailers) in context of online demand fulfillment remains a rather understudied area. However, there have been few studies wherein supply side risks are taken into account in context of retailer-retailer and retailer-supplier collaboration (Shu et al., 2018). An enormous number of products are available in the retailing market and each of the products follows a specific 
Ghadge, A., Bag, S., Goswami, M. and Tiwari, MK. (2020), "Mitigating demand risk of durable goods in online retailing", International Journal of Retail and Distribution Management, forthcoming.

Table 1: Contrasting our work with recent studies

\begin{tabular}{|c|c|c|c|c|c|c|}
\hline \multirow[t]{2}{*}{ Authors } & \multirow{2}{*}{$\begin{array}{l}\text { Research study type and primary focus } \\
\text { Analytical (A); Empirical (E); Case-based (C) }\end{array}$} & \multicolumn{5}{|c|}{ Key elements of study } \\
\hline & & $\begin{array}{l}\text { Demand risk } \\
\text { management }\end{array}$ & $\begin{array}{l}\text { Collaboration } \\
\text { mechanism }\end{array}$ & $\begin{array}{l}\text { Product } \\
\text { representation }\end{array}$ & $\begin{array}{l}\text { Revenue/ } \\
\text { economic } \\
\text { modeling }\end{array}$ & $\begin{array}{l}\text { Other research } \\
\text { dimensions }\end{array}$ \\
\hline $\begin{array}{l}\text { Sohrabi } \\
\text { et al. } \\
(2020)\end{array}$ & $\begin{array}{l}\text { PMID model with robust modeling based on } \\
\text { stochastic programming- (A) }\end{array}$ & $\begin{array}{l}\text { Deterministic } \\
\text { demand }\end{array}$ & - & $\begin{array}{l}\text { Product } \\
\text { attribute level } \\
\text { based }\end{array}$ & $\begin{array}{l}\text { Revenue } \\
\text { maximization }\end{array}$ & $\begin{array}{l}\text { Optimization model, } \\
\text { competitive offerings, } \\
\text { information } \\
\text { asymmetry }\end{array}$ \\
\hline $\begin{array}{l}\text { Zheng et } \\
\text { al. (2020) }\end{array}$ & $\begin{array}{l}\text { Comparison of self-supporting, third-party, and co- } \\
\text { distribution mode for e-commerce for case JD.COM- } \\
\text { (C) }\end{array}$ & $\begin{array}{l}\text { Big data } \\
\text { driven mining }\end{array}$ & $\begin{array}{l}\text { Collaboration } \\
\text { with } 3^{\text {rd }} \text { party } \\
\text { for distribution }\end{array}$ & $\begin{array}{l}\text { Service } \\
\text { platform based }\end{array}$ & - & $\begin{array}{l}\text { e-commerce, Big } \\
\text { data, distribution } \\
\text { mode }\end{array}$ \\
\hline $\begin{array}{l}\text { Huang et } \\
\text { al. }(2020)\end{array}$ & $\begin{array}{l}\text { Analytical expressions for customer choice and } \\
\text { market outcomes- (A) }\end{array}$ & $\begin{array}{l}\text { Consumer } \\
\text { uncertainty }\end{array}$ & - & $\begin{array}{l}\text { Product } \\
\text { attribute level } \\
\text { based }\end{array}$ & $\begin{array}{l}\text { Consumer } \\
\text { welfare, } \\
\text { recoverable } \\
\text { costs }\end{array}$ & $\begin{array}{l}\text { Product line design, } \\
\text { return policy and } \\
\text { refunds }\end{array}$ \\
\hline $\begin{array}{l}\text { Koos et } \\
\text { al.(2019) }\end{array}$ & $\begin{array}{l}\text { Based on Logit regression showcasing relation } \\
\text { between customer satisfaction and stockouts (A) }\end{array}$ & - & & $\begin{array}{l}\text { Utilitarian and } \\
\text { attribute level } \\
\text { based }\end{array}$ & $\begin{array}{l}\text { Customer } \\
\text { dissatisfaction } \\
\text { cost }\end{array}$ & $\begin{array}{l}\text { Consumer behavior, } \\
\text { reference point effect, } \\
\text { stock-outs }\end{array}$ \\
\hline $\begin{array}{l}\text { Bag et } \\
\text { al.(2019) }\end{array}$ & $\begin{array}{l}\text { Multi-linear and neural network based models for } \\
\text { establishing relationships between products' attribute } \\
\text { levels and purchase intentions (E) }\end{array}$ & - & - & $\begin{array}{l}\text { Product } \\
\text { attribute level } \\
\text { based }\end{array}$ & $\begin{array}{l}\text { Customer } \\
\text { purchase } \\
\text { intentions }\end{array}$ & $\begin{array}{l}\text { Online search, } \\
\text { consumers review, } \\
\text { sentiment analysis }\end{array}$ \\
\hline $\begin{array}{l}\text { Shaban et } \\
\text { al.(2019) }\end{array}$ & $\begin{array}{l}\text { Simulation based collaboration models for } \\
\text { minimizing demand uncertainty (A) }\end{array}$ & $\begin{array}{l}\text { Impulse } \\
\text { demand and } \\
\text { upward shift } \\
\text { demand }\end{array}$ & $\begin{array}{l}\text { Supplier- } \\
\text { retailer- } \\
\text { distributor } \\
\text { collaboration }\end{array}$ & - & $\begin{array}{l}\text { Production } \\
\text { and inventory } \\
\text { costs }\end{array}$ & $\begin{array}{l}\text { Classical order-up-to, } \\
\text { Bullwhip, Net stock } \\
\text { amplification }\end{array}$ \\
\hline $\begin{array}{l}\text { Zhang et } \\
\text { al.(2019) }\end{array}$ & $\begin{array}{l}\text { Game theoretic analysis of horizontal carrier } \\
\text { coordination with revenue sharing in E-commerce } \\
\text { logistics (A) }\end{array}$ & $\begin{array}{l}\text { Price and } \\
\text { service level } \\
\text { driven demand }\end{array}$ & $\begin{array}{l}\text { Collaboration } \\
\text { between e- } \\
\text { retailer and } \\
\text { logistic service } \\
\text { providers }\end{array}$ & - & $\begin{array}{l}\text { Revenue } \\
\text { sharing } \\
\text { contact based } \\
\text { on power and } \\
\text { Cournot game }\end{array}$ & $\begin{array}{l}\text { Horizontal } \\
\text { coordination, service } \\
\text { supply chain }\end{array}$ \\
\hline $\begin{array}{l}\text { This } \\
\text { research } \\
(2020)\end{array}$ & $\begin{array}{l}\text { Mitigating demand risk of durable goods in online } \\
\text { retailing for major e-retailing methods (A) }\end{array}$ & $\begin{array}{l}\text { Uncertain } \\
\text { customer } \\
\text { demand }\end{array}$ & $\begin{array}{l}\text { Collaboration } \\
\text { amongst e- } \\
\text { retailer }\end{array}$ & $\begin{array}{l}\text { Product } \\
\text { attribute level } \\
\text { based }\end{array}$ & $\begin{array}{l}\text { Economic loss } \\
\text { minimization } \\
\text { to e-retailer }\end{array}$ & $\begin{array}{l}\text { Opportunity cost, } \\
\text { customer un- } \\
\text { satisfaction cost }\end{array}$ \\
\hline
\end{tabular}


category. It has been observed in the literature that consumers can rather compromise on a few attributes (such as price) of durable goods if they are highly satisfied with others attributes (Bronnenberg et al. 2016; Bag et al. 2019). In such cases, a similar category of unavailable products can be suggested to customers to reduce the opportunity cost and customer dissatisfaction cost. Another way to handle demand risk is to collaborate with other e-retailer. In view of such nuances, this research proposes an e-retailer to e-retailer collaboration model to mitigate the uncertain demand risk and minimize the economic loss of durable goods. Table 1 contrasts our work with some of the other important recent studies.

To the best of the authors' knowledge, there is lack of studies that contrasts dominant demand fulfillment methods (mechanisms) of e-retailers, while considering associated economic loss, when the product demand is uncertain. We seek to develop an integrated model, wherein such nuances are modelled. In particular, our model has similarities with respect to the Newsvendor models, aimed at predicting the right level of order quantities considering demand uncertainties. A crucial limitation of such model is that it assumes that the demand follows certain probabilistic (discrete/continuous) or stochastic distribution, without considering product characteristics (Dai et al. 2015; Alwan et al. 2016; Xu et al. 2017). Interestingly, current research lacks the link between product attribute driven product characterization and modelling of economic loss to e-retailers.

This research seeks to address highlighted research gap by taking into account product characteristics in terms of product attribute levels. The study also develops a generalized architecture for handling and ascertaining optimal policy for the selection of suitable demand fulfillment method, considering the cost components associated with economic loss; viz. product obsolescence cost, inventory cost, customer unsatisfaction cost and opportunity cost.

\section{Research methodology}

To carry out the research, secondary data related to consumers' search and transaction history have been collected from Informs pubs online repository (Bronnenberg et al. 2016). Varieties of camera products which were purchased in the period of three months (October-December 2010) are taken into account for this analysis. Further, various camera attributes like Brand, Display, Pixel, Sensor, Zoom, Face Detection, Image Stabilization, Model, Movie, SLR are considered for attribute level analysis. Attribute level demand forecasting has been shown in Algorithm 1 (refer to Appendix). 
This study has used a Weighted Moving Average (WMA) method to forecast 4 weeks demand of products' attributes of an e-retailer. The same algorithm is used to forecast the demand of products' attributes across all e-retailers. The weights of the WMA method are generated from the consumers' purchased history.

Typically, Multiple Linear Regression performs well while forecasting demand when multiple seasonality related trends are present in the dataset (Marcjasz et al. 2019). However, the dataset used in this research has only three months' data and a high volume of purchase has been observed in the month of December. Monthly seasonality data is not available in the dataset. Thus Multiple Linear Regression is not of much utility for selected dataset, as weekly seasonality is present in the dataset. The weighted moving average method is based on the weights of different days of the week and recent trends. Thus, weighted moving average method is found to be appropriate for the used dataset.

Traditional e-retailing method is associated with storing a certain number of products based on the forecasted demand. However, uncertain product demand increases likelihood of product unavailability (out-of-stock) for e-retailers resulting in increased customer dissatisfaction, higher search costs, and inflated purchasing lead times. In this research, the concept of memory management is mapped with e-retailing scenario and based on it three methods are presented in Table 2 for handling uncertain demand risk. The concept of memory management (cache memory and main memory) has been further detailed in left side of Table 2 . In the memory management of computer operating system, most frequently used data is stored in cache memory and rest of useful data is kept in main memory. Then, three methods, namely, Direct Mapping, Fully Associative, and Set Associative Mapping are used to perform the memory management operation. Here, the memory management method of Direct Mapping is compared with Alternative products' suggestion from own e-retailing method. Then, Fully Associative approach is mapped with selling unavailable products from collaborative partner. Finally, Set Associative method is compared with mixed method of selling unavailable products from collaborative partner and alternative products' suggestion from own e-retailing method.

Referring to Table 2, the memory management processes illustrate, what is the corresponding action at the systems level of the website, when a certain action is performed on the e-retailer's website. Memory management essentially provides understanding of the working of dynamic memory allocation and de-allocation for different e-retailing actions (such as buying a 
preferred product or buying an alternate product based on recommendations) on the e-retailer's website.

Table 2: Mapping memory management with e-retailing scenarios

\begin{tabular}{|c|c|}
\hline Cache and main memory management & Proposed e-retailing approaches \\
\hline Memory & $\begin{array}{l}\text { Entire e-retailing } \\
\text { marketplace }\end{array}$ \\
\hline $\begin{array}{l}\text { Cache memory is a small high-speed memory. It } \\
\text { stores data from some frequently used addresses } \\
\text { of main memory. }\end{array}$ & $\begin{array}{l}\text { Amazon is a popular e-retailer in the e-commerce } \\
\text { market. Suppose it keeps high demand products in } \\
\text { the online marketplace. }\end{array}$ \\
\hline $\begin{array}{l}\text { A Cache miss means when data not found in the } \\
\text { cache. This result in extra delay called missed } \\
\text { penalty. }\end{array}$ & $\begin{array}{l}\text { Product misses means when product not found in a } \\
\text { single e-retailing store. This results in lost } \\
\text { opportunity cost, customer dissatisfaction etc. }\end{array}$ \\
\hline $\begin{array}{l}\text { After a Cache miss, processor fetches data from } \\
\text { main memory and copies into the cache. Three } \\
\text { methods perform while cache misses data. } 1 . \\
\text { Direct Mapping, 2. Fully Associative, 3. Set } \\
\text { Associative Mapping }\end{array}$ & $\begin{array}{l}\text { After product miss, e-retailer suggests products from } \\
\text { alternative products store or collaborative partner } \\
\text { marketplace and sells it to the customer. Three } \\
\text { approaches can be applied while product is not found } \\
\text { in simple e-retailing method. 1. Exact product } \\
\text { suggestion from collaborative e-retailer, } 2 . \\
\text { Alternative product suggestion from own e-retailing } \\
\text { store, 3. Alternative product suggestion from other e- } \\
\text { retailing stores }\end{array}$ \\
\hline $\begin{array}{l}\text { Direct Mapped: Memory block mapped into one } \\
\text { and only Cache line. Miss rate increases due to a } \\
\text { possible increase of mapping conflicts. }\end{array}$ & $\begin{array}{l}\text { Exact product suggestion from collaborative e- } \\
\text { retailer: Missed products directly loaded to e- } \\
\text { retailer from other collaborative e-retailing } \\
\text { marketplace(s). Profit decreases due to selling from } \\
\text { other e-retailing marketplaces. The purpose of this } \\
\text { method is to satisfy the customer by providing their } \\
\text { desired products. }\end{array}$ \\
\hline $\begin{array}{l}\text { Fully Associative mapping: A Cache where data } \\
\text { from any address can be stored in any cache } \\
\text { location. }\end{array}$ & $\begin{array}{l}\text { Alternative product suggestion from own e- } \\
\text { retailing store: The aim of this method is to divert } \\
\text { the consumers from high demand products to } \\
\text { relatively low demand products while ensuring that } \\
\text { purchase intentions are not diluted. The demand can } \\
\text { be shifted based on recommending limited inventory } \\
\text { products to high value customers, and adequate } \\
\text { inventory products to every user. }\end{array}$ \\
\hline $\begin{array}{l}\text { Set Associative mapping: Cheaper than a fully } \\
\text { associative cache. Lower miss ratio than a direct } \\
\text { mapped cache. But the direct-mapped cache is the } \\
\text { fastest. }\end{array}$ & $\begin{array}{l}\text { Mixed method: In this method, unavailable } \\
\text { products are suggested from the alternative product } \\
\text { of own e-retailing store and collaborative partners' } \\
\text { marketplace. }\end{array}$ \\
\hline
\end{tabular}




\section{Framework for managing uncertain demand in e-retailing}

The aim of this study is to minimize the economic losses which is generated from uncertain products demand. A conceptual architecture of proposed uncertain demand handling approach for durable goods is presented in Figure 1. The study has been performed based on three steps. In the first step, demands of product and attributes have been forecasted for both single and across all eretailing company. The second step is to predict consumers purchase intention. In the final stage, four methods viz. a) Traditional e-retailing method with storing extra products, b) Alternative products' suggestion from own e-retailing method, c) Selling unavailable products from collaborative partner, d) Mixed method of selling unavailable products from collaborative partner and alternative products' suggestion from own e-retailing method have been proposed.

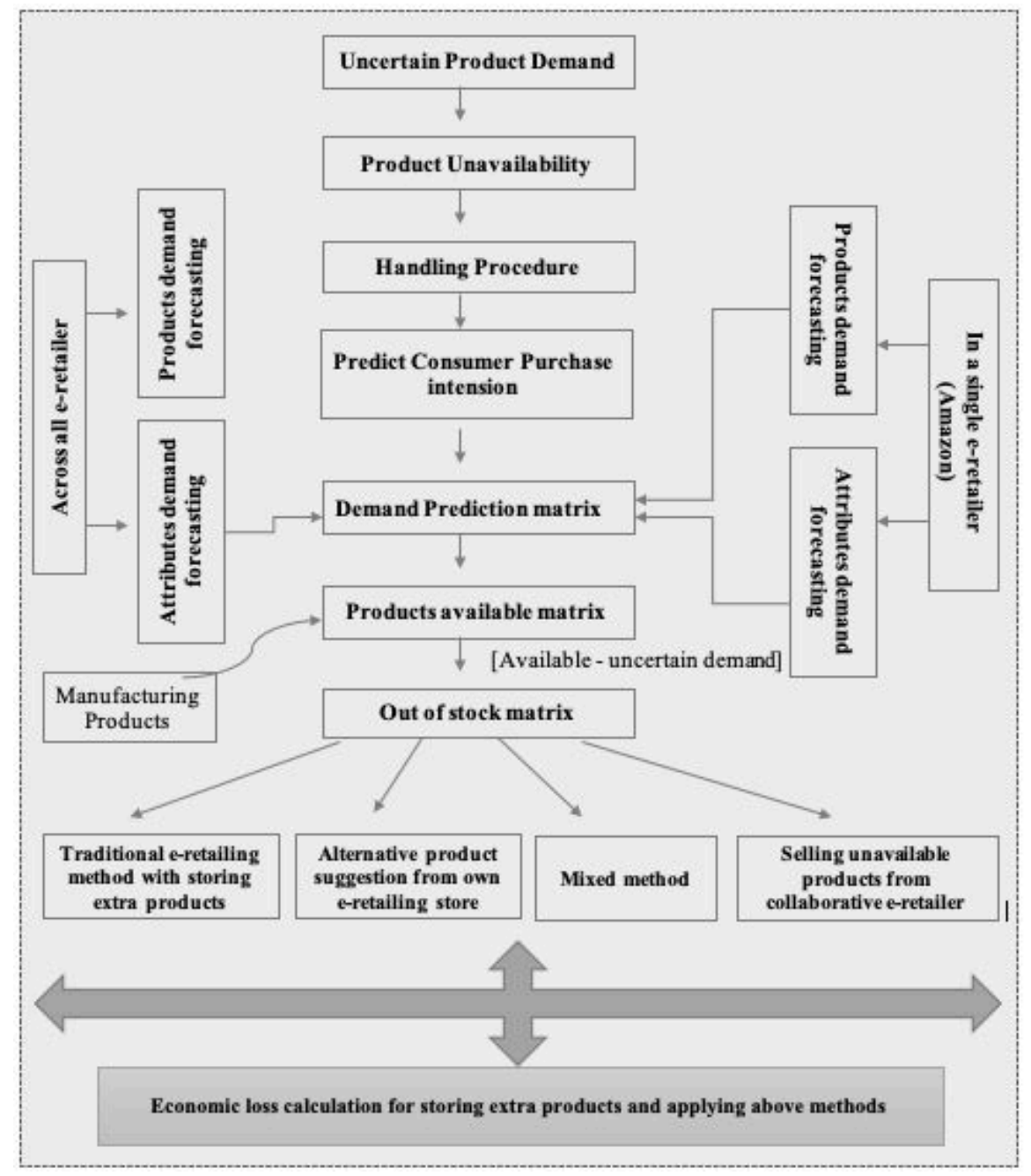

Figure 1: The architecture for uncertain demand handling approach for durable goods 


\section{Settings of the analysis}

Last 4 weeks of three months periods' (October-December, 2010) data (Bronnenberg et al. 2016) have been forecasted using a Weighted Moving Average (WMA) method. The method has been forecasted to have consumers purchasing 147 products whereas consumers actually purchased 167 products from a single e-retailer- Amazon. Similarly, consumers actually purchased 532 products across all e-retailer, whereas the forecasting method projected that consumers would purchase 497 products across all e-retailer. Here, uncertain product demands of 20 and 35 have been observed in Amazon and across all e-retailer, respectively. This study is performed for a single e-retailer to analyze and handle the uncertain products demand. As for a single e-retailer, Amazon, forecasted demand $\left(F_{d}\right)=147$, actual demand $\left(A_{d}\right)=167$, uncertain demand $\left(U_{d}\right)=20$, total price of actual demanded products $=38106(\$)$ (total price is calculated from the used purchasing dataset), price/product $=228$, price of forecasted demand products $=33516(\$)$, revenue loss $=4560(\$)$. A cost matrix has been assumed to be given as apriori based on average product price in Table 3 to calculate the economic loss due to uncertain products demand.

Table 3: Cost matrix to calculate the economic loss due to uncertain products demand

\begin{tabular}{|l|c|c|c|}
\hline Parameters & Usual cost $(\$)$ & $\begin{array}{c}\text { Selling risk cost } \\
(\$)\end{array}$ & $\begin{array}{c}\text { Effective } \\
\text { cost }(\$)\end{array}$ \\
\hline Inventory cost (including interest) / product $\left(I_{c}\right)$ & $\begin{array}{c}2.5 \% \text { of Product } \\
\text { Price }(6)\end{array}$ & 0 & 6 \\
\hline $\begin{array}{l}\text { Profit by selling product from own e-retailing store } \\
\left(P_{o}\right) \text { / Loss of opportunity cost per product }\left(L_{\text {ocp }}\right)\end{array}$ & $\begin{array}{c}25 \% \text { of Product } \\
\text { Price }\end{array}$ & 0 & 50 \\
\hline $\begin{array}{l}\text { Profit by selling alternative product from own e- } \\
\text { retailing store }\left(P_{\text {aow }}\right)\end{array}$ & $\begin{array}{c}22 \% \text { of Product } \\
\text { Price (57) }\end{array}$ & $\begin{array}{c}7.5 \% \text { of Product } \\
\text { Price }(17)\end{array}$ & 40 \\
\hline $\begin{array}{l}\text { Profit by selling product from other e-retailing stores } \\
\left(P_{\text {oth }}\right)\end{array}$ & $\begin{array}{c}19 \% \text { of Product } \\
\text { Price (34) }\end{array}$ & $\begin{array}{c}1.75 \% \text { of } \\
\text { Product Price }(4)\end{array}$ & 30 \\
\hline $\begin{array}{l}\text { Profit by selling alternative product from other e- } \\
\text { retailing stores }\left(P_{\text {aoth }}\right)\end{array}$ & $\begin{array}{c}15 \% \text { of Product } \\
\text { Price (43) }\end{array}$ & $\begin{array}{c}8 \% \text { of Product } \\
\text { Price }(18)\end{array}$ & 25 \\
\hline Customer un-satisfaction $\left(U_{c}\right)$ & $\begin{array}{c}1.3 \% \text { of Product } \\
\text { Price (3) }\end{array}$ & 0 & 3 \\
\hline Obsolescence risk cost / products $\left(O_{c}\right)$ & $\begin{array}{c}0.9 \% \text { of Product } \\
\text { Price (2) }\end{array}$ & 0 & 2 \\
\hline
\end{tabular}

The cost values provided in Table 3 follows a certain rationale. To start with, we have assumed that the maximum theoretical profit is $25 \%$ of the product price. It corresponds to the 
setting, wherein the e-retailer sells the desired product from its own channel. However, when the e-retailer is not able to sell the desired product and makes a recommendation for the alternative product, the profit margin is modelled to shrink in; since the e-retailer is not able to provide the desired product. Furthermore, when the e-retailer enables customer purchases from other collaborative e-retailer(s), it is assumed that profit margin for the given e-retailer would shrink further, since the e-retailer is using the sales channel of collaborative e-retailer(s). In order to model the customer unsatisfaction cost and product obsolescence cost, this study adheres to the findings of Koos et al. (2019) and Mantrala et al. (2019). They argue and illustrated that in a long run, the costs related to customer dissatisfaction and product obsolescence typically are often a fraction of the maximum theoretical profit.

An important input that goes into the analysis is the consumers' transaction data. Consumers' transaction data is often very sensitive in the nature. Attribute level consumers' transaction data for durable goods is rarely available in the public domain. The data set used for this study is along the line of Bronnenberg et al. (2016); where, comScore log files containing complete URL-level browsing history and a separate file for all online transactions for a set of online purchasers between October and December 2010 were used. As the entire comScore file runs into several terabytes, it is simply infeasible to sample all householders making online transactions for their purchases. Further, a three month period has been found to be adequate for reasonable sampling from the entire panel data of households making online purchase of the product under consideration in this study. The primary reason for this is that, an observation period of three months ensures inclusion of majority of those customers, such that the span of associated purchase process (starting from having an intention to purchase to making a final online purchase) remained within specific interval of three months (Bronnenberg et al. 2016).

Now, the economic loss is calculated from Table 3 for a traditional e-retailing method when no extra product is store in the inventory.

Economic loss $=$ Uncertain products demand * (loss opportunity cost due to products unavailability + customer un-satisfaction cost)

$$
=U_{d} *\left(L_{o c p}+U_{c}\right)=20 *(50+3)=1060(\$)
$$

If e-retailer store doubles the demand forecasted products to avoid loss opportunity cost then, 
Total extra products will be stored in the inventory $\left(S_{e p}\right)=\left(2 * F_{d}\right)-A_{d}=(147 * 2)-167=127$.

In such case, inventory cost and obsolescence risk cost will be increased significantly.

Here, economic loss for storing extra products,

$=$ Inventory cost + obsolescence risk cost for storing extra products

$=S_{e p} *\left(I_{c}+O_{c}\right)=127 *(6+2)=1016(\$)$

Hence, storing a high volume of extra products is also not a good way to handle uncertain products demand. Therefore, four methods such as traditional method with storing extra products, collaborative method, alternative products suggestion method, and mixed method have been proposed to reduce the economic loss in uncertain product demand. E-retailers can satisfy customers for uncertain products demand (here it is 20) based on either storing extra products or collaborating with other e-retailers. Alternative products suggestion from own and other e-retailers is also a way to minimize the demand risk. Algorithm 2 presents the process ascertaining economic loss for storing a different percentage of forecasted products and applying four e-retailing methods (provided in Appendix).

\section{Results and discussions}

The uncertain demand is handled based on attribute level demand forecasting and by applying different e-retailing approaches. Different economic loss parameters are calculated based on variations in storing 100 to 200 percentage of forecasted products in the inventory. Figure 2 presents the loss of selling opportunity of products for storing a different percentage of forecasted products in inventory. Further, Figure 2 shows total of how many products left in the inventory corresponding to storing different percentages of forecasted products. A trade-off between loss of opportunity in selling a specific attribute's products and number of same attribute's products left in the inventory. 


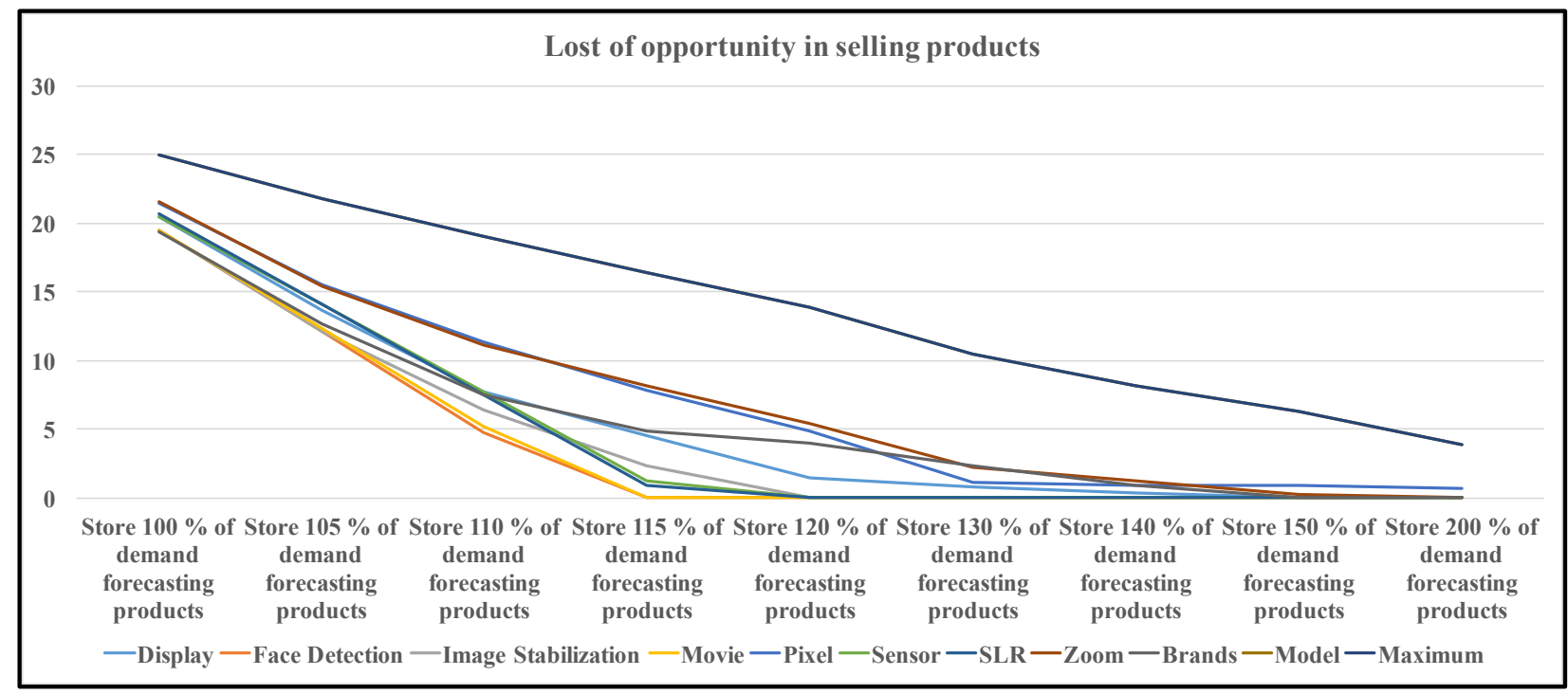

Figure 2: Loss of selling opportunity for storing a different percentage of forecasted products

Referring to Figure 2, it can be ascertained that customers view the attributes of product under consideration in terms of the amalgamation of different product attributes in which different product attributes have different associated levels of opportunity lost costs. This is consistent with theory of product characterization based on product attribute levels, where customers associate varying level of affinities corresponding to different product attributes (Sohrabi et al. 2020). In context of this research and from the consumer affinity standpoint, the attributes "movie" and "zoom" are perhaps the least and most preferred respectively. The reason for this is that in case of product attribute "movie", the opportunity lost cost approaches to zero at around 115\% storage level of demand forecasting. However, in this case of "zoom", the opportunities lost cost approaches to zero around a much higher level i.e. beyond $150 \%$ storage level of demand forecasting. 


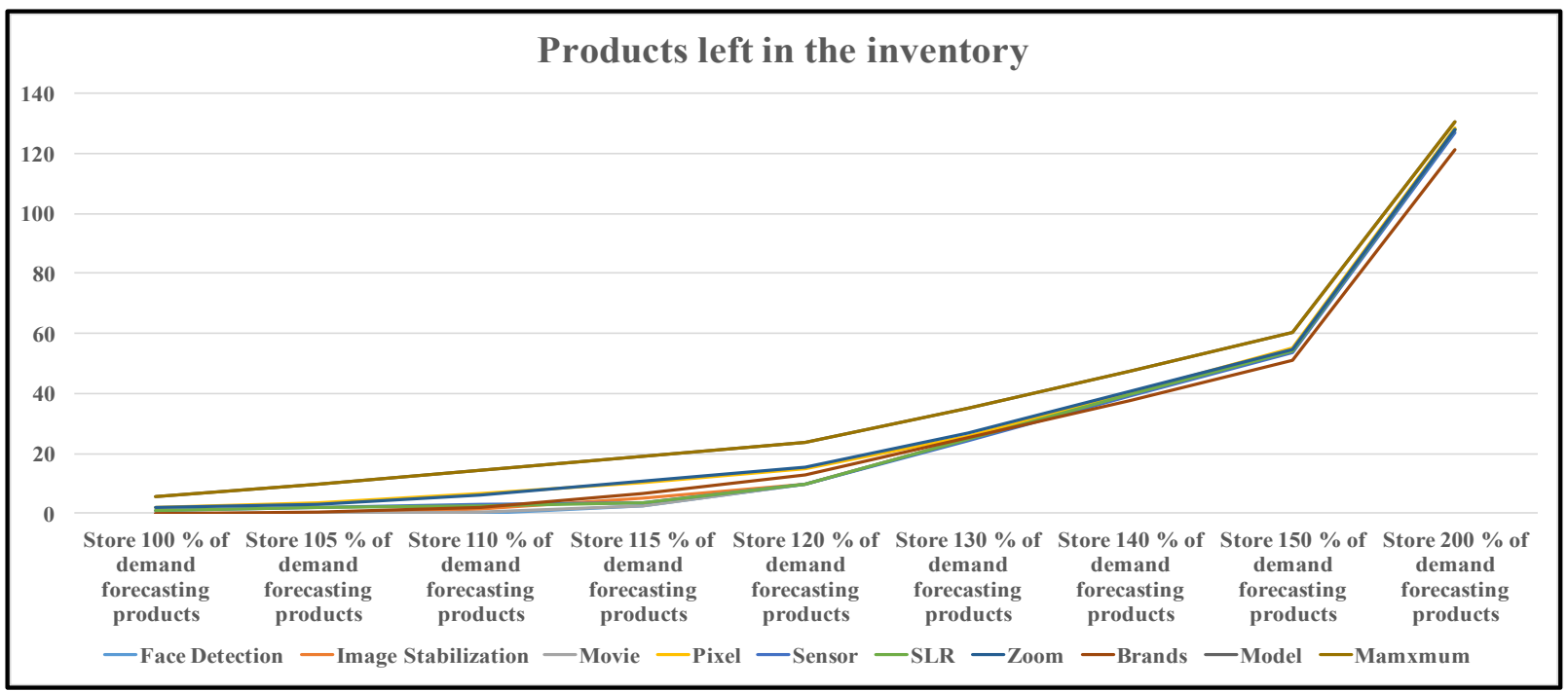

Figure 3: Products left in the inventory for storing a different percentage of forecasted products

Figure 3 represents the economic loss for applying four different e-retailing methods. It is evidently noticed that the mixed method always performs well compared to other e-retailing approaches. Further, the economic loss is minimized while e-retailer applies collaborative eretailing approach and store $115 \%$ of demand forecasting products in the inventory. After storing $115 \%$ of demand forecasted products, e-retailer is able to satisfy consumer's uncertain products demand through alternative products from own e-retailer. Therefore, the economic loss for storing (115 to 200) \% of demand forecasting products is the same for both alternative product suggestion and mixed methods.

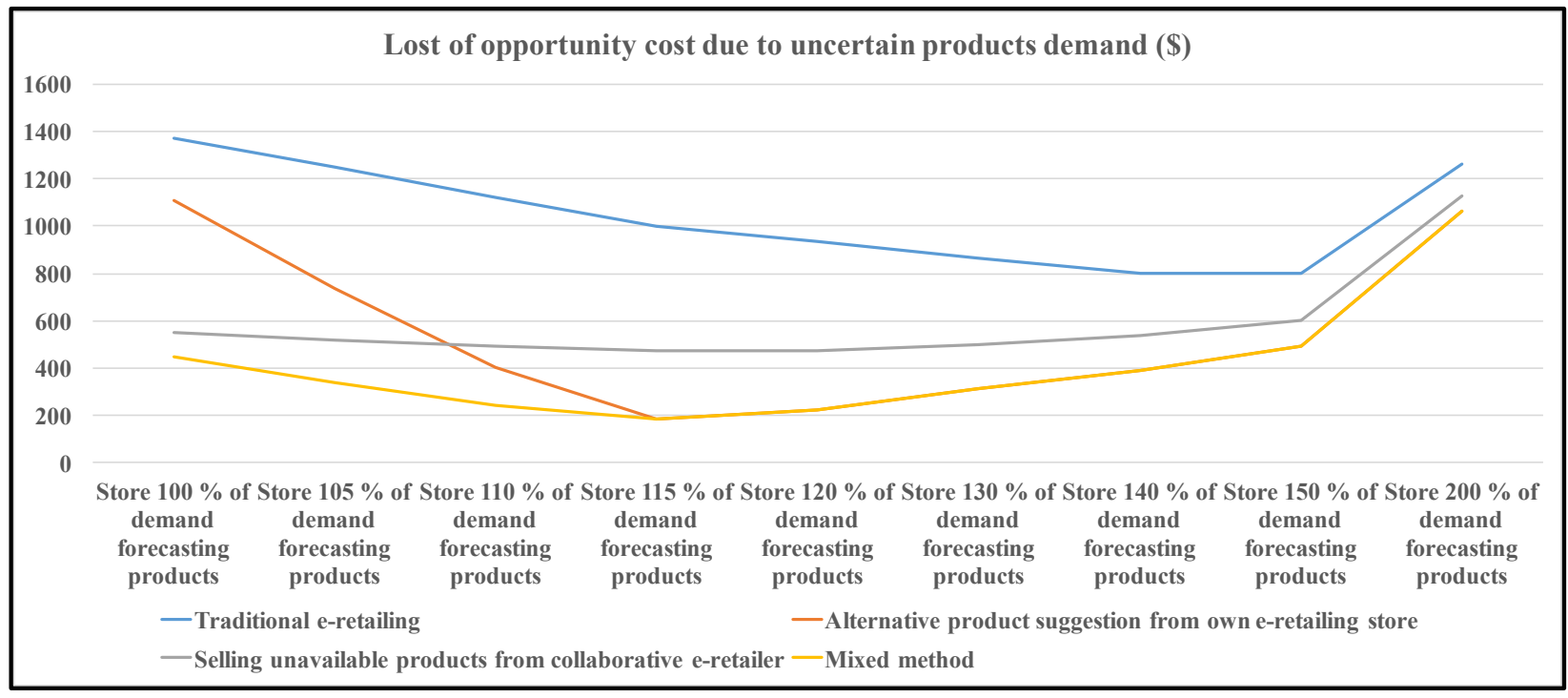

Figure 4: Economic loss for applying different methods 
The outcomes of the four methods such as traditional e-retailing with storing extra products, alternative products suggestion from own e-retailing, selling unavailable products from collaborative partner and mixed method were captured. Loss of opportunity cost, customer unsatisfaction cost, inventory cost, obsolescence risk cost, and economic loss were calculated, while storing different percentages of forecasted products in the inventory.

\section{Findings and implications}

Results of attribute level forecasted products demand are useful for both e-retailers as well as manufacturers. The results can suggest e-retailer to perform proper inventory management and collaboration with other e-retailer, and manufacturers to manufacturing influential products. Suppose the sensor attribute CCD seems high in demand, thus, an e-retailer can store more products which contain CCD sensor. The demand-supply gap of a product varies among different e-retailers. Thus, collaborative e-retailing method can be adhered to mitigate uncertain demand risk and increase the profit of a single and all e-retailing company. Moreover, products and attributes demand across all e-retailer suggests manufactures to produce high demand products and attributes. For instance, the display size 2.7 and 3.0 inches are high demand display size, thus, manufacturers can produce more products of this display size.

In the next stage, economic loss is calculated for applying different methods. It is observed that the economic loss has been minimized while traditional e-retailer store $150 \%$ of forecasted products in the inventory. Moreover, it is noticed that the economic loss has been drastically minimized while e-retailer uses collaborative e-retailing method and store only $115 \%$ of demand forecasting products in the inventory. The method of selling unavailable products from collaborative e-retailer increases consumer's satisfaction but decreases the profit for sharing it with associate e-retailer. The mixed method performs better than any other approaches. The mixed method suggests e-retailer to store optimized number of products to minimize the economic loss. In this study, all other 37 e-retailers have been considered as a collaborative partner. As a result, all unavailable products are getting exactly available in the collaborative marketplace and thus, alternative products suggestion from the collaborative marketplace is not required. It may require while e-retailer collaborate with a limited number of other e-retailers. Table 4 further contrasts the four e-retailing scenarios in terms of economic loss. 
Table 4: Contrasting e-retailing methods with respect to economic loss

\begin{tabular}{|l|l|l|l|l|l|l|}
\hline $\begin{array}{l}\text { e-retailing } \\
\text { approaches }\end{array}$ & $\begin{array}{l}\text { Best } \\
\text { option }\end{array}$ & $\begin{array}{l}\text { Worst } \\
\text { option }\end{array}$ & $\begin{array}{l}\text { Maximum } \\
\text { value of } \\
\text { economic } \\
\text { los demand } \\
\text { forecasting products }\end{array}$ & $\begin{array}{l}\text { Minimum } \\
\text { value of } \\
\text { economic } \\
\text { loss }\end{array}$ & $\begin{array}{l}\text { Expected } \\
\text { value of } \\
\text { economic } \\
\text { loss }\end{array}$ & $\begin{array}{l}\text { \% deviation with } \\
\text { respect to } \\
\text { expected value }\end{array}$ \\
\hline $\begin{array}{l}\text { Traditional } \\
\text { e-retailing }\end{array}$ & $140 \%$ & $200 \%$ & 1260 & 798 & 9393 & $2.15 \%$ \\
\hline $\begin{array}{l}\text { Alternate } \\
\text { product } \\
\text { suggestion }\end{array}$ & $115 \%$ & $200 \%$ & 1064 & 184 & 4913 & $6.65 \%$ \\
\hline $\begin{array}{l}\text { Collaborative } \\
\text { e-retailer }\end{array}$ & $120 \%$ & $200 \%$ & 1128 & 472 & 5268 & $3.71 \%$ \\
\hline $\begin{array}{l}\text { Mixed } \\
\text { method }\end{array}$ & $115 \%$ & $200 \%$ & 1064 & 180 & 3692 & $6.80 \%$ \\
\hline
\end{tabular}

Referring to Table 4, it can be inferred that storing $200 \%$ of the demand forecasting products is perhaps the worst case for all the e-retailing approaches. Two e-retailing scenarios, i.e. alternate product suggestion and mixed method fetch the minimal economic loss corresponding to the situation, when the e-retailer stores $115 \%$ of the demand forecasting products. However, out of the four approaches, the best scenario corresponds to the mixed method (alternate product suggestion + collaborative e-retailer) wherein the e-retailer store $115 \%$ of the demand forecasting products. From an optimistic and pessimistic perspective (considering the minimum and maximum values of economic loss), the two approaches i.e. alternate product suggestion and mixed method, yields the lower value of economic losses. Considering the expected value of the economic losses (assuming same likelihood associated with 9 possible discrete variations starting from $100 \%$ of the demand forecasting products to $200 \%$ of the demand forecasting products), mixed method yields the lowest value of economic loss. A possible downside however associated with the two retailing approaches is that, both are associated with higher variations wrt. the expected value of economic loss. 


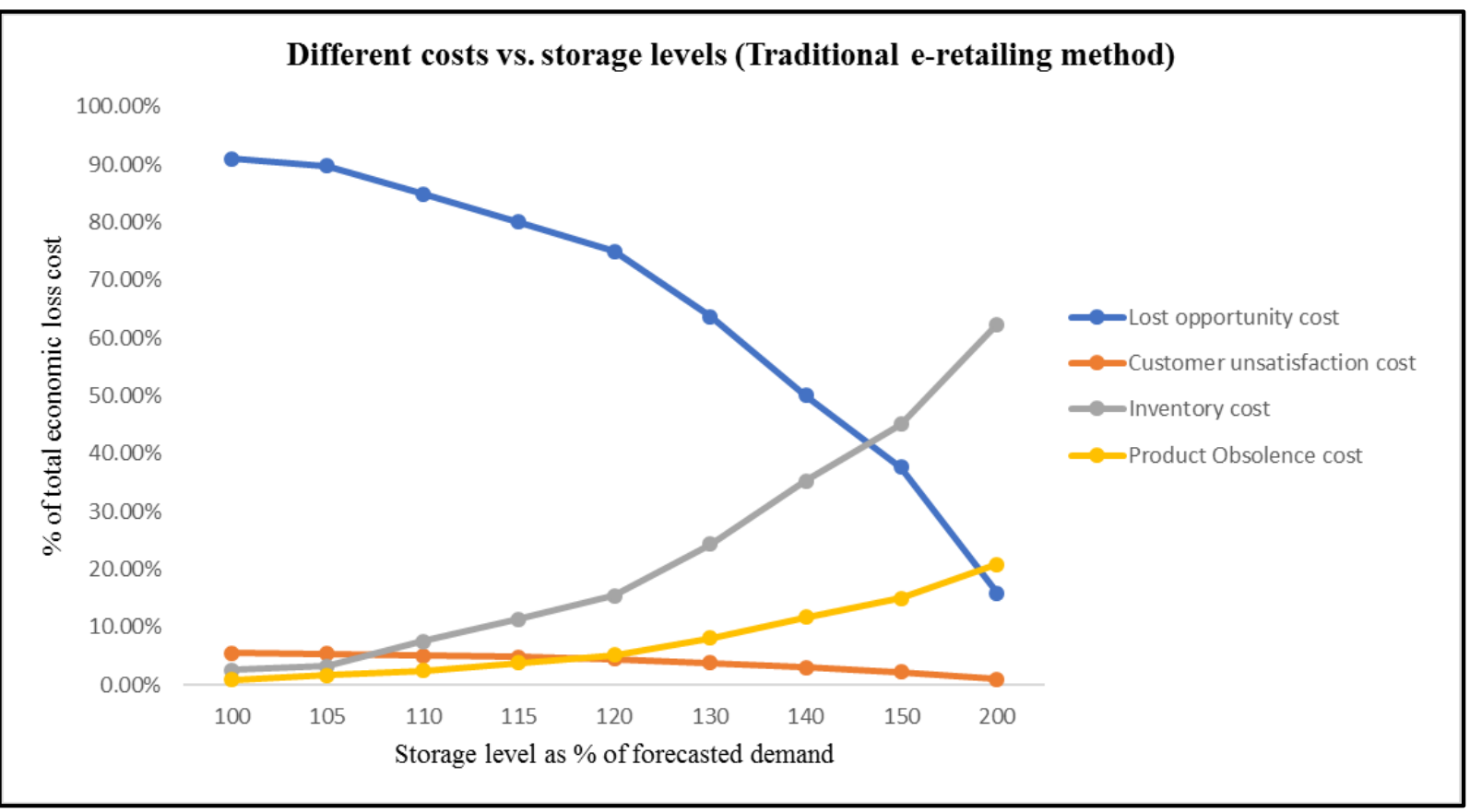

Figure 5(a): Traditional e-retailing method

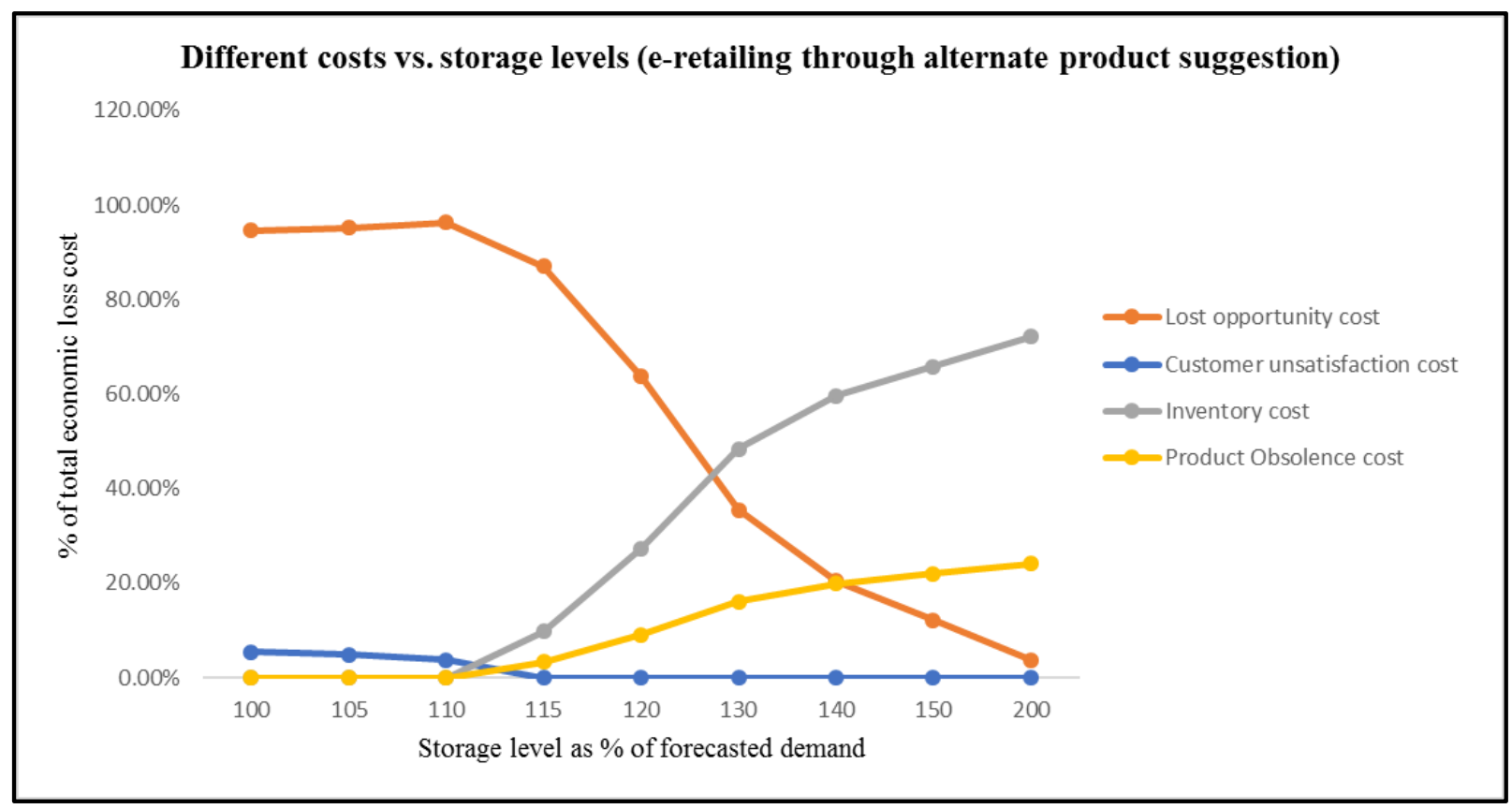

Figure 5(b): Alternate product suggestion 


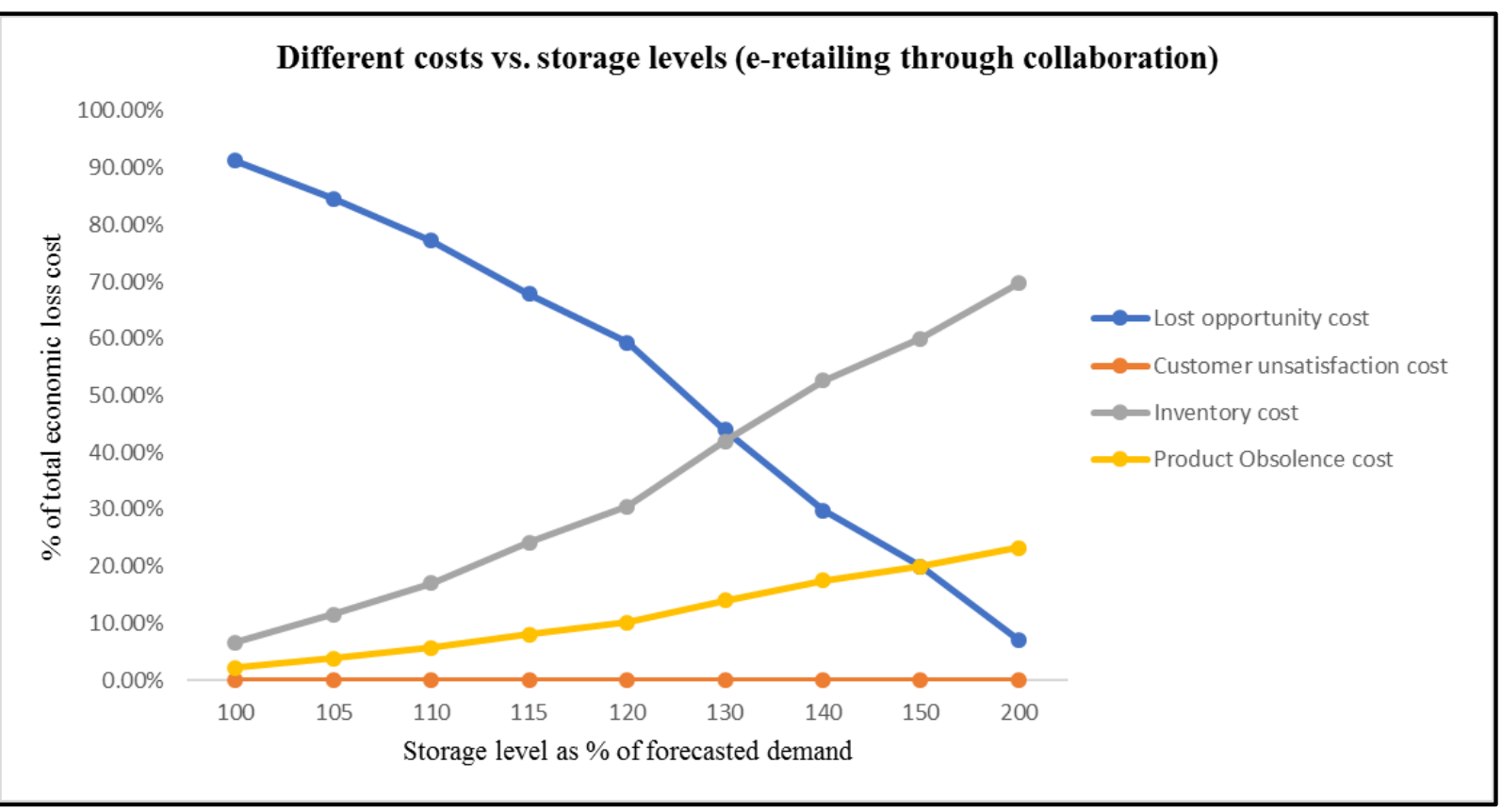

Figure 5(c): Collaboration

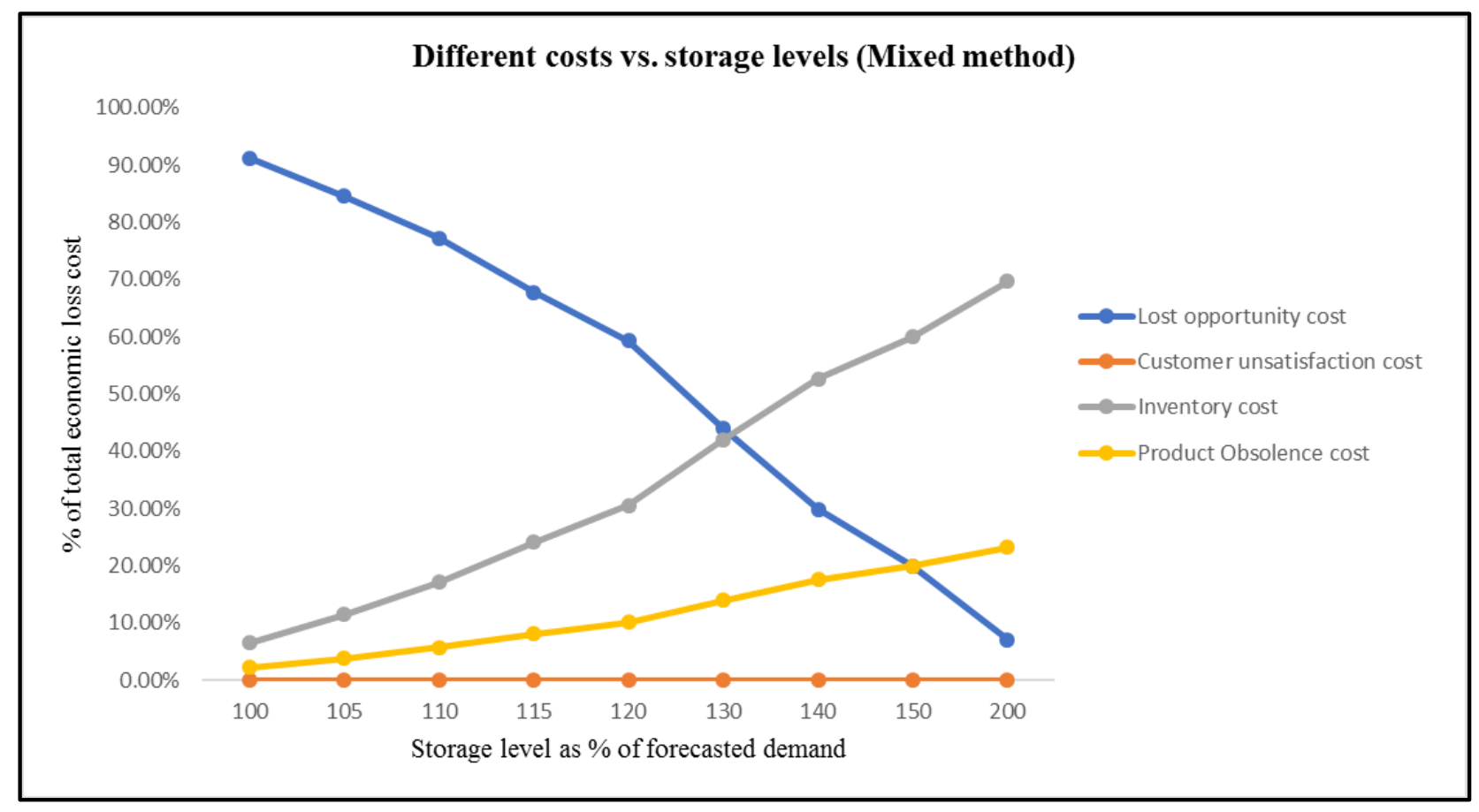

Figure 5(d): Mixed e-retailing method

Figure 5: Mix of different cost elements corresponding to the four e-retailing scenarios 
Figure 5 depicts the respective proportions of the four cost elements corresponding to the four different e-retailing scenarios. It is to be noted that, in all the four e-retailing scenarios, two costs elements i.e. lost opportunity cost and inventory cost are most dominant, followed by obsolescence cost and customer unsatisfaction cost. Further, the customer unsatisfaction cost is observed to be zero in case of mixed e-retailing and collaborative mode of e-retailing, corresponding to all storage levels. A key implication of this observation is that e-retailers must either consider mixed mode or collaborative mode of e-retaining, particularly in the situations wherein customers value purchase of specific products (as opposed to going to alternate products). Further, product obsolescence cost is observed in all the e-retailing scenarios. However, in case of alternate product suggestion mode of e-retailing, the product obsolescence cost is observed beyond $110 \%$ storage level of the forecasted demand. This finding has implication for the inventory planning and storage level for alternate product, wherein product obsolescence cost is significant, for instance in the case of white goods.

\section{Conclusion and avenues for future research}

In this study, an attribute level demand forecasting method has been deployed to forecast attributes' demand of a particular category of durable goods (camera). Moreover, the demand of the camera products for all e-retailing websites are also forecasted which is helpful for high in demand e-retailer to collaborate with low in demand e-retailer and vice versa. For instance, Amazon.com, Bestbuy.com, and Walmart.com are leading e-retailing website. Therefore, these high demand e-retailers can collaborate with other low demand e-retailers like Argos.co.uk, Staples.com, Tigerdirect.com to fulfil win-win objectives. Recently, various companies have collaborated with Amazon to increase their respective marketplace visibility. However, their collaboration is not aimed to fulfil consumers' demand of unavailable products; they only have collaborated considering select best products of associate e-retailer (Argos 2019).

The study contributes to the extant literature in that retailer to retailer collaboration approach has been proposed as a way to mitigate the demand uncertainty. In this study, four approaches such as traditional e-retailing method with storing extra products, alternative product suggestion from own e-retailer, selling unavailable products from a collaborative e-retailing partner, and mixed method have been performed to handle the uncertain demand and minimized the economic loss. Moreover, the attribute level demand forecasting method for durable goods can 
help researcher to incorporate and extend this model in their research problem. In addition to proposing four e-retailing methods, this study contributes to practice in the following ways. The research is performed to increase customer satisfaction and reduce the lost opportunity cost based on solving products unavailability problem. As a result of consumer's satisfaction, the brand value of e-retailing company can also be increased. The proposed mixed e-retailing method reduces the inventory cost and obsolescence risk cost based on suggesting appropriate products to store in the inventory. Diversity in products selling can also be increased by using alternative products suggestion method. Moreover, proposed four methods for handling uncertain demand risk can also be used for mitigating demand risk of different categories of products like mobile, automobile, laptop, TV, Refrigerators, Air Conditioners, and medical equipment etc.

However, this study has few limitations which can be catered to in the future. Limited numbers of risk factors have been considered in this study. In the future, others risk factors like fraudulent o- rder of high demanded products risk, long delivery time window risk, damage and return risk of popular products can be incorporated and handled to reduce the economic loss. Additionally, various influential factors like sales, discount, offers, and deals etc. can also be incorporated to make the model more real life. In this research a single category of durable goods is considered, further proposed methods can be examined on non-durable and finite number of other durable goods. Mainly, in this study, a pilot study has been evolved by only considering the three months' consumers purchase data. In the future, Big data analysis can be performed for analyzing extensive historical data. Particularly, high-performance extreme learning machine can be performed for predicting consumer purchase intention, forecasting demand and handling product's uncertain demand.

In the future, more practical factors such as quantity discounts, seasonal and periodic offers and inventory clearances could be incorporated to make the evolved model robust. In particular, considering the extent of quantity discounts based on the purchases from both individuals and businesses would enable e-retailers to carry out their sales and operational planning for both segments. Along the similar lines, future study focused on impact of periodic offers on e-retailer's bottom-line in varying geographies would enable e-retailers to tailor their method of e-retailing. Ongoing COVID-19 pandemic has changed purchasing behavior of consumers, thus it may be timely to explore other innovative approaches e-retailers can use to offer their product lines. 


\section{Acknowledgment:}

Authors would like to thank two reviewers and editor for their constructive recommendations for improving the quality of manuscript.

\section{References}

Afrin, Kahkashan, Bimal Nepal, and Leslie Monplaisir. 2018. “A Data-Driven Framework to New Product Demand Prediction: Integrating Product Differentiation and Transfer Learning Approach.” Expert Systems with Applications 108. Elsevier: 246-257.

Alonso-Ayuso, Antonio, Laureano F Escudero, Monique Guignard, and Andres Weintraub. 2018.

"Risk Management for Forestry Planning under Uncertainty in Demand and Prices." European Journal of Operational Research 267 (3). Elsevier: 1051-1074.

Alwan, Lathy C., Minghui Xu, Dong-Ying Yao and Xiaohang Yue. 2016. " The Dynamic Newsvendor Model with Correlated Demand", Decision Sciences, 47(1), 11-30.

Andersson, Tommy, Albin Erlanson, Jens Gudmundsson, Helga Habis, J Ingebretsen Carlson, and Jörgen Kratz. 2014. “A Method for Finding the Maximal Set in Excess Demand.” Economics Letters 125 (1). Elsevier: 18-20.

Antoniadis, Ioannis, Symeon Paltsoglou, and Vasilis Patoulidis. 2019. "Post Popularity and Reactions in Retail Brand Pages on Facebook." International Journal of Retail \& Distribution Management. Emerald Publishing Limited.

Argos, Shop. 2019. "Best Selling Products from Argos." https://www.amazon.co.uk/Argos/b/ref=bl_dp_s_web_1660670031?ie=UTF8\&node=16606 70031.

Ashton, Triss, and Victor R. Prybutok, 2020, " Developing and validating e-retailing satisfaction scales with text-mining", Journal of Modeling in Management, DOI 10.1108/JM2-09-20190218

Aydinliyim, Tolga, Michael S Pangburn, and Elliot Rabinovich. 2017. "Inventory Disclosure in Online Retailing.” European Journal of Operational Research 261 (1). Elsevier: 195-204. Bag, Sujoy, Tiwari, Manoj Kumar and Felix T S Chan. 2019. "Predicting the Consumer's Purchase Intention of Durable Goods: An Attribute-Level Analysis.” Journal of Business Research 94. Elsevier: 408-419. doi:https://doi.org/10.1016/j.jbusres.2017.11.031. 
Bag, Sujoy., Ghadge, Abhijeet. and Tiwari, Manoj Kumar. 2019. "An integrated recommender system for improved accuracy and aggregate diversity", Computers \& Industrial Engineering, 130, 187-197.

Bell, David. R., Santiago, G., and Antonio, Moreno, 2018 "Offline Showrooms in Omnichannel Retail: Demand and Operational Benefits", Management Science, 64(4), 1629-1651.

Bellini, Silvia, and Simone Aiolfi. 2019. "Impulse Buying Behavior: The Mobile Revolution." International Journal of Retail \& Distribution Management. Emerald Publishing Limited.

Bronnenberg, Bart J., Jun B. Kim, and Carl F. Mela. 2016. "Zooming in on Choice: How Do Consumers Search for Cameras Online?” Marketing Science 35 (5). INFORMS: 693-712.

Chatfield, Dean C, Jeon G Kim, Terry P Harrison, and Jack C Hayya. 2004. "The Bullwhip Effect - impact of Stochastic Lead Time, Information Quality, and Information Sharing: A Simulation Study." Production and Operations Management, 13 (4). Wiley Online Library: 340-353.

Choi, Tsan-Ming. 2018. "Launching the Right New Product among Multiple Product Candidates in Fashion: Optimal Choice and Coordination with Risk Consideration." International Journal of Production Economics 202. Elsevier: 162-171.

Chung, Wenming, Srinivas Talluri, and Ram Narasimhan. 2011. "Price Markdown Scheme in a Multi-Echelon Supply Chain in a High-Tech Industry." European Journal of Operational Research 215 (3). Elsevier: 581-589.

Cosgun, Özlem, Ufuk Kula, and Cengiz Kahraman. 2017. "Markdown Optimization for an Apparel Retailer under Cross-Price and Initial Inventory Effects." Knowledge-Based Systems 120. Elsevier: 186-197.

Costantino, Francesco, Giulio Di Gravio, Ahmed Shaban, and Massimo Tronci. 2013. "Information Sharing Policies Based on Tokens to Improve Supply Chain Performances." International Journal of Logistics Systems and Management 14 (2). Inderscience Publishers Ltd: $133-160$.

Costantino, Francesco, Giulio Di Gravio, Ahmed Shaban, and Massimo Tronci. 2014. "The Impact of Information Sharing and Inventory Control Coordination on Supply Chain Performances." Computers \& Industrial Engineering 76. Elsevier: 292-306.

Costantino, Francesco, Giulio Di Gravio, Ahmed Shaban, and Massimo Tronci. 2015. "The Impact of Information Sharing on Ordering Policies to Improve Supply Chain Performances." 
Computers \& Industrial Engineering 82. Elsevier: 127-142.

Costantino, Francesco, Giulio Di Gravio, Ahmed Shaban, and Massimo Tronci. 2016. "Smoothing Inventory Decision Rules in Seasonal Supply Chains." Expert Systems with Applications 44. Elsevier: 304-319.

Dadouchi, C, and B Agard. 2018. "Lowering Penalties Related to Stock-Outs by Shifting Demand in Product Recommendation Systems." Decision Support Systems 114. Elsevier: 61-69.

Dai, Jiansheng, and Weidong Meng. 2015. " A risk-averse newsvendor model under marketingdependency and price-dependency". International Journal of Production Economics, 160(2015), 220-229.

Ehrenthal, J C F, Dorothée Honhon, and Tom Van Woensel. 2014. "Demand Seasonality in Retail Inventory Management.” European Journal of Operational Research 238 (2). Elsevier: 527 539.

Geng, Shidao, Wenli Li, Xiaofei Qu, and Lirong Chen. 2017. "Design for the Pricing Strategy of Return-Freight Insurance Based on Online Product Reviews." Electronic Commerce Research and Applications 25. Elsevier: 16-28.

Gutiérrez, Sonia San Mart’'in, Carmen Camarero Izquierdo, and Rebeca San José Cabezudo. 2010.

"Product and Channel-Related Risk and Involvement in Online Contexts." Electronic Commerce Research and Applications 9 (3). Elsevier: 263-273.

He, Yongfu, and Harmen Oppewal. 2018. "See How Much We've Sold Already! Effects of Displaying Sales and Stock Level Information on Consumers' Online Product Choices." Journal of Retailing 94 (1). Elsevier: 45-57.

Hong, Ilyoo B. 2015. "Understanding the Consumer's Online Merchant Selection Process: The Roles of Product Involvement, Perceived Risk, and Trust Expectation.” International Journal of Information Management 35 (3). Elsevier: 322-336.

Howland, Daphne. 2018. "Out-of-stocks could be costing retailers \$1T", RetailDive. Accessed: $21^{\text {st }}$ July, 2020. Available at https://www.retaildive.com/news/out-of-stocks-could-becosting-retailers-1t/526327/

Huang, Xiao and Dan Zhang. 2020. "Service Product Design and Consumer Refund Policies", Marketing Science, 39(2), 366-381.

Jahani, Hamed, Babak Abbasi, Farzad Alavi Fard, and Srinivas Sri Talluri. 2018. "Supply Chain Network Redesign with Demand and Price Uncertainty." International Journal of Production 
Economics 205. Elsevier: 287-312.

Jang, Sungha, Ashutosh Prasad, and Brian T Ratchford. 2017. "Consumer Search of Multiple Information Sources and Its Impact on Consumer Price Satisfaction.” Journal of Interactive Marketing 40. Elsevier: 24-40.

Kim, Jeeyeon, Mingyung Kim, Jeonghye Choi, and Minakshi Trivedi. 2017. "Offline Social Interactions and Online Shopping Demand: Does the Degree of Social Interactions Matter?" Journal of Business Research. Elsevier.

Kiran, M., Vamsee, Krishna, R. E. Vinodhini, R. Archanaa, K. VImalkumar. 2017. " User specific product recommendation and rating system by performing sentiment analysis on product reviews", 4th International Conference on Advanced Computing and Communication Systems (ICACCS)

Kok, A Gurhan, and Marshall L Fisher, 2007. " Demand Estimation and Assortment Optimization Under Substitution: Methodology and Application", Operations Research, 55(6), 1001-1021. Koos, Shelby E, and Nazrul I Shaikh. 2019. 'Dynamics of Consumers' Dissatisfaction due to Stock-Outs." International Journal of Production Economics, Elsevier: 461-471.

Lachapelle, Ugo. 2018. "Employer Subsidized Public Transit Pass: Assessing Disparities in Access, Use, and Latent Demand." Case Studies on Transport Policy 6 (3). Elsevier: 353363.

Lee, Wan-I, Shan-Yin Cheng, and Yu-Ta Shih. 2017. "Effects among Product Attributes, Involvement, Word-of-Mouth, and Purchase Intention in Online Shopping." Asia Pacific Management Review 22 (4). Elsevier: 223-229.

Lombart, Cindy, and Didier Louis. 2012. "Consumer Satisfaction and Loyalty: Two Main Consequences of Retailer Personality." Journal of Retailing and Consumer Services 19 (6). Elsevier: 644-652.

Mantrala, Murali K., Michael Levi, Barbara E., Kahn, Edward J. Fox, Peter Gaidarev, Bill Dankworth, and Denish Shah. 2009, "Why is Assortment Planning so Difficult for Retailers? A Framework and Research Agenda", Journal of Retailing, 85(1), 71-83.

Ma, Shanshan, Guo Li, Suresh P Sethi, and Xuan Zhao. 2018. "Advance Selling in the Presence of Market Power and Risk-Averse Consumers." Decision Sciences. Wiley Online Library. Marcjasz, Grzegorz, Bartosz Uniejeswki, and Rafal Weron. 2019. "On the importance of the longterm seasonal component in day-ahead electricity price forecasting with NARX neural 
networks", International Journal of Forecasting, 35(4), 1520-1532.

Martin, Jillian, Gary Mortimer, and Lynda Andrews. 2015. "Re-Examining Online Customer Experience to Include Purchase Frequency and Perceived Risk." Journal of Retailing and Consumer Services 25. Elsevier: 81-95.

Merzifonluoglu, Yasemin. 2015. "Impact of Risk Aversion and Backup Supplier on Sourcing Decisions of a Firm." International Journal of Production Research 53 (22). Taylor \& Francis: 6937-6961.

Mukhopadhyay, Somnath, Subhashish Samaddar, and Glenn Colville. 2007. "Improving Revenue Management Decision Making for Airlines by Evaluating Analyst-Adjusted Passenger Demand Forecasts." Decision Sciences 38 (2). Wiley Online Library: 309-327.

Nagare, Madhukar, and Pankaj Dutta. 2018. "Single-Period Ordering and Pricing Policies with Markdown, Multivariate Demand and Customer Price Sensitivity." Computers \& Industrial Engineering 125. Elsevier: 451-466.

$\mathrm{Ni}$, Guanqun, Li Luo, Yinfeng Xu, and Jiuping Xu. 2015. "Optimal Online Markdown and Markup Pricing Policies with Demand Uncertainty." Information Processing Letters 115 (11). Elsevier: 804-811.

Osei-Frimpong, Kofi. 2019. "Understanding Consumer Motivations in Online Social Brand Engagement Participation: Implications for Retailers." International Journal of Retail \& Distribution Management 47 (5). Emerald Publishing Limited: 511-529.

Pantano, Eleonora, Simona Giglio, and Charles Dennis. 2018. "Making Sense of Consumers' Tweets: Sentiment Outcomes for Fast Fashion Retailers through Big Data Analytics." International Journal of Retail \& Distribution Management. Emerald Publishing Limited. Papanagnou, Christos I, and Omeiza Matthews-Amune. 2018. "Coping with Demand Volatility in Retail Pharmacies with the Aid of Big Data Exploration." Computers \& Operations Research 98. Elsevier: 343-354.

Parsa, Payam, Manuel D Rossetti, Shengfan Zhang, and Edward A Pohl. 2017. "Quantifying the Benefits of Continuous Replenishment Program for Partner Evaluation." International Journal of Production Economics 187. Elsevier: 229-245.

Rosenblum, Paula. 2014. "How Walmart Could Solve Its Inventory Problem And Improve Earnings", Forbes. Accessed 21 ${ }^{\text {st }}$ July, 2020 available at: https://www.forbes.com/sites/paularosenblum/2014/05/22/walmart-could-solve-its- 
inventory-problem-and-improve-earnings/\#5cc93c2c5db1

Sarangi, Subrat, and Shreyas Srivatsan. 2009. "Interrelationship between Operations and Marketing in Reducing Demand Risk." Journal of Marketing Channels 16 (3). Taylor \& Francis: 227-243.

Shaban, Ahmed, Francesco Costantino, Giulio Di Gravio, and Massimo Tronci. 2019. "A New Efficient Collaboration Model for Multi-Echelon Supply Chains.” Expert Systems with Applications 128. Elsevier: 54-66.

Shu, Lei, Feng Wu, and Lap Keung Chu. 2017. "Risk-Averse Procurement Strategy under LargeScale Promotion Online Considering Strategic Customer." Computers \& Industrial Engineering 112. Elsevier: 576-585.

Shu, Shu, Xirui Yang, Chen Shou, Shouyang Wang, Kin Keung Lai and Honglin Yang. 2018. "Retailers' Order Strategies in Transshipments in Disruption Risks of Supply Chains", Journal of Systems Science and Complexity, 31(2018), 1273-1301.

Sodhi, ManMohan S. 2005. "Managing Demand Risk in Tactical Supply Chain Planning for a Global Consumer Electronics Company." Production and Operations Management 14 (1). Wiley Online Library: 69-79.

Sohrabi, Arya, Mir Saman Pishvaee, Ashkan Hafezalkotob, and Sharooz Bamdad. 2020. "A multiattribute model to optimize the price and composition of prepaid mobile Internet plans", Journal of Enterprise Information Management, DOI: 10.1108/JEIM-09-2019-0279

Wang, Xun, and Stephen M Disney. 2016. "The Bullwhip Effect: Progress, Trends and Directions." European Journal of Operational Research 250 (3). Elsevier: 691-701.

Xu, Xun, Charles L Munson, and Shuo Zeng. 2017. "The Impact of E-Service Offerings on the Demand of Online Customers." International Journal of Production Economics 184. Elsevier: 231-244.

Xu, Xun, Shuo Zeng, and Yuanjie He. 2017. "The Influence of E-Services on Customer Online Purchasing Behavior toward Remanufactured Products." International Journal of Production Economics 187. Elsevier: 113-125.

Xu, Xingshen, Hongwei Wang, and Chuangyin Dang and Ping Ji. 2017. " The loss-averse newsvendor model with backordering", International Journal of Production Economics, 188(2017), 1-10.

Yan, Nina, Liu Yang, Xu Xun, and He Xiuli, 2020, " Strategic dual-channel pricing games with e- 
retailer finance", European Journal of Operational Research, 283(1), 138-151.

Yu, Biao, Han Zhao, and Deyi Xue. 2017. "A multi-population co-evolutionary genetic programming approach for optimal mass customisation production.", International Journal of Production Research, 55(3), 621-641. Kuzmanovic, Marija, and Milan Martic, 2012. "An approach to competitive product line design using conjoint data.", Expert Systems with Application, 39(8), 7262-7269.

Zarandi, M H Fazel, and F Shabany Moghadam. 2017. "Fuzzy Knowledge-Based Token-Ordering Policies for Bullwhip Effect Management in Supply Chains." Knowledge and Information Systems 50 (2). Springer: 607-631.

Zhang, Mengdi, Yufang, Yu, Zhiheng, Zhao, Saurabh Pratap, George Q. Huang. 2019 "Game theoretic analysis of horizontal carrier coordination with revenue sharing in E-commerce logistics", International Journal of Production Research, 57(5), 1524-1551.

Zhang, Linghong, and Jingguo Wang. 2017. "Coordination of the Traditional and the Online Channels for a Short-Life-Cycle Product." European Journal of Operational Research 258 (2). Elsevier: 639-651.

Zhang, Mingyang, Juliang Zhang, T C E Cheng, and Guowei Hua. 2018. "Why and How Do Branders Sell New Products on Flash Sale Platforms?" European Journal of Operational Research 270 (1). Elsevier: 337-351.

Zheng, Kangning, Zuopeng Zhang (Justin), Bin Songd, 2020. "E-commerce logistics distribution mode in big-data context: A case analysis of JD.COM", Industrial Marketing Management, 86(2020), 154-162.

Zhu, Bing, Suwanna Kowatthanakul, and Punnaluck Satanasavapak. 2019. "Generation Y Consumer Online Repurchase Intention in Bangkok." International Journal of Retail \& Distribution Management. Emerald Publishing Limited.

Zhuang, Hejun, Peter T L Popkowski Leszczyc, and Yuanfang Lin. 2018. "Why Is Price Dispersion Higher Online than Offline? The Impact of Retailer Type and Shopping Risk on Price Dispersion.” Journal of Retailing. Elsevier. 
Ghadge, A., Bag, S., Goswami, M. and Tiwari, MK. (2020), "Mitigating demand risk of durable goods in online retailing", International Journal of Retail and Distribution Management, forthcoming.

\section{APPENDIX}

Algorithm 1 : Attribute level demand forecasting to mitigate uncertain demand risk of camera products

Input : Attribute level consumers ' purchase data of three months in a sin gle e-retailer

Output : Forecasted demand of attributes

1: $P_{h s}=\left(\begin{array}{l}P_{h s} M, P_{h s} T u, P_{h s} W, P_{h s} T h, \\ P_{h s} F, P_{h s} S, P_{h s} S n\end{array}\right), / * P_{h s}$ is the purchase histery in each day ofthe week of an eretailer */

$2:$ Attributes $=\left(\begin{array}{l}\text { Brand, Display, Pixel, Sensor, Zoom, Face Detection, } \\ \text { Image Stabilization, Model, Movie, SLR }\end{array}\right)$,

$3:$ Brand $=\left(\begin{array}{l}\text { CANON SONY KODAK PANASONIC NIKON FUJI CASIO SAMSUNG PENTAX } \\ \text { VIVITAR POLAROID FISHER-PRICE GE SEALIFE LEICA SIGMA RICOH }\end{array}\right)$,

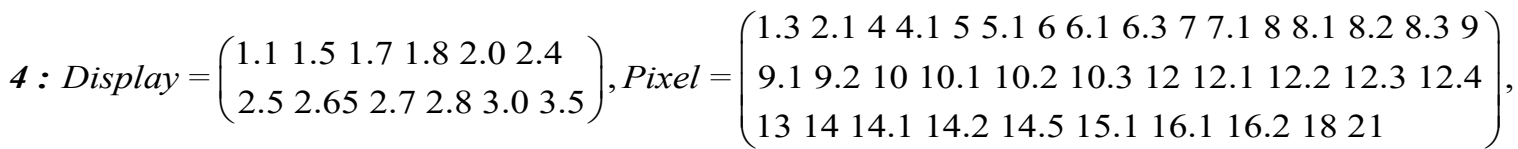

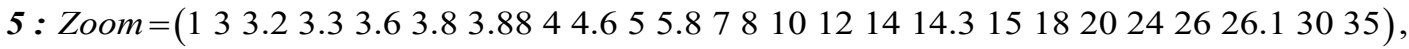

6: Sensor $=($ CCD CMOS BSI-CMOS $)$, Face Detection $=($ NonFD FD $)$, Image Stabilization $=($ NonIS IS $)$,

$7:$ Model $=\left(\begin{array}{l}\text { D90 D40 XSi T2i XT T1i XTi S90 ZS7 D5000 G10 D60 ZS3 G11 LX3 G9 D300s GF1 } \\ \text { D7000S95 XS S5 SD780 D3000 TX7 TZ5 GH1 G1 Z915 D10S70 SX10 S3000 LX5 }\end{array}\right)$,

$\boldsymbol{8}:$ Movie $=($ NonMovie Movie $), S L R=($ NonSLR SLR $)$

9: for the attribute $a=1$ to Count (Attributes) do

10: $U_{d}(a)=0, E S_{I}(a)=0 \quad / * U_{d}(a)=$ Uncertain demand of attribute $a * /$

11: for the attribute category ac $=1$ to Count $(\operatorname{Attributes}(a))$ do

12: $T A_{d}(a c)=0, T F_{d}(a c)=0$

13: for the dayi $=F_{d u}+1$ to $N_{d}$ do $/ * N_{d}=$ Number of days historical data(here, 105 days $) * /$

14: $\quad F_{d}(i)=0 \quad / * F_{d}(i)=$ Forecasted demand for day $i * /$

15: for the forcasted day $j=1$ to $P_{w m a}$ do $/ * P_{w m a}=$ Period of weighted moving average $=7$ days $* /$

16: $\quad F_{d}(i)=F_{d}(i)+\left(\left(P_{h s}(j) / \operatorname{Sum}\left(P_{h s}(j)\right)\right) * A_{d}(i-j)\right)$

17: if $\left(N_{d}-i\right)>k$ then $/ * k$ is demand forecasting duration (here, 28 days)*/

18: $\quad T F_{d}(a c)=T F_{d}(a c)+F_{d}(i)$

19: $\quad T A_{d}(a c)=T A_{d}(a c)+A_{d}(i)$

20: $\quad$ end if

21: end for

22: end for

23: if $T A_{d}(a c)>T F_{d}(a c)$ then $/ * T F_{d}(a c)=$ Total Forecasted demand for ac $* /$

24: $\quad U_{d}(a)=U_{d}(a)+\left(T A_{d}(a c)-T F_{d}(a c)\right) / * T A_{d}(a c)=$ Total actual demand for ac $* /$

25: else $E S_{I}(a)=E S_{I}(a)+\left(T F_{d}(a c)-T A_{d}(a c)\right) / * E S_{I}(a)=$ Extra store in inventory of attribute $a * /$

26: end if

27 : end for

28 :end for 
Ghadge, A., Bag, S., Goswami, M. and Tiwari, MK. (2020), "Mitigating demand risk of durable goods in online retailing", International Journal of Retail and Distribution Management, forthcoming.

Algorithm 2 : Economic loss for storing extra products and applying different e-retailing methds

Input : Attribute level demand forecasting data, Actual purchase data

Output : Economic loss for applying different e - retailing methds

$1:$ StoringMatrix $=\{100,105,110,115,120,130,140,150,200\}$

$2:$ for the attribute $a=1$ to Count (Attributes) do

3: $U_{d}(a$, Count $($ StoringMatrix $))=\{0\}, E S_{I}($ a, $\operatorname{Count}($ StoringMatrix $))=\{0\}$

4: for the attribute category ac $=1$ to Count $($ Attributes $(a))$ do

5 : $\quad$ for storing different percentage of forecasted data $i=1$ to Count (StoringMatrix) do

6 : $\quad T_{s}(a c, i)=T F_{d}(a c) *\left(\frac{\text { StoringMatrix }(i)}{100}\right) / * T_{s}=$ Storing total extra products in inventory $* /$

$7: \quad$ if $T A_{d}(a c)>T_{s}(a c, i)$ then

8: $\quad U_{d}(a, i)=U_{d}(a, i)+\left(T A_{d}(a c)-T_{s}(a c, i)\right)$

9: $\quad$ else $E S_{I}(a, i)=E S_{I}(a, i)+\left(T_{s}(a c, i)-T A_{d}(a c)\right)$

10: end if $/ * P_{o}=$ Profit by selling product from own e-retailing store* $/$

11: end for $/ * P_{\text {aow }}=$ Profit by selling alternative product from own e-retailing store $* /$

12 : end for $/ * P_{o t h}=$ Profit by selling product from other $e$-retailing stores $* /$

13 :end for $\quad / * L_{\text {ocp }}=$ Loss of opportunity cost per product $* /$

14 : for storing different percentage of forecasted data $i=1$ to Count(StoringMatrix) do

15: $M U_{d}=\operatorname{Max}\left(U_{d}(, i)\right), M E S_{I}=\operatorname{Max}\left(E S_{I}(, i)\right) / * M E S_{I}=$ Maximum stored attribute in inventory $* /$

$16 / *$ Traditional $\boldsymbol{e}$ - retailing method $* / \quad / * M U_{d}=$ Maximum uncertain attribute demand $* /$

17: $T L_{c}=M U_{d} *\left(L_{o c p}\right), T U_{c}=M U_{d} *\left(U_{c}\right) / * T L_{c}=$ Total loss of opportunity cost $* /$

18: $T I_{c}=M E S_{I} *\left(I_{c}\right), T O_{c}=M E S_{I} *\left(O_{c}\right) / * T I_{c}=$ Total inventory cost $* /$

19: EconomicLossTM $=T L_{c}+T U_{c}+T I_{c}+T O_{c} / * T U_{c}=$ Total customer unsatisfaction cost $* /$

$20 / *$ Alternative product suggestion method */ $\quad / * T O_{c}=$ Total obsolescence risk cost $* /$

21: $T L_{c}=\operatorname{Max}\left(T L_{c}-M E S_{I} * P_{\text {aow }}, 0\right), T U_{c}=\operatorname{Max}\left(T U_{c}-M E S_{I} * U_{c}, 0\right)$

22: $T I_{c}=\operatorname{Max}\left(T I_{c}-M E S_{I}^{*} I_{c}, 0\right), T O_{c}=\operatorname{Max}\left(T O_{c}-M E S_{I} * O_{c}, 0\right)$

23: EconomicLossAPM $=T L_{c}+T U_{c}+T I_{c}+T O_{c}$

$24 / *$ Mixed e - retailing method */ / $/ N o$ Change in $T I_{c}$ and $\mathrm{TO}_{c} * /$

25: $T L_{c}=T L_{c}-\left(M U_{d}-M E S_{I}\right) * P_{o t h}, T U_{c}=0$

26: EconomicLossMM $=T L_{c}+T U_{c}+T I_{c}+T O_{c}$

$27 / *$ Selling unavailable products from collaborative e - retailer method * /

28: $T L_{c}=M U_{d} *\left(L_{\text {ocp }}-P_{\text {oth }}\right), T U_{c}=0$

29: $T I_{c}=M E S_{I} * I_{c}, T O_{c}=M E S_{I} * O_{c}$

30: EconomicLossACM $=T L_{c}+T U_{c}+T I_{c}+T O_{c}$

31: MinEconomicLoss $=\operatorname{Min}\left(\begin{array}{l}\text { EconomicLossTM, EconomicLossAPM, } \\ \text { EconomicLossMM,EconomicLossACM }\end{array}\right)$

32 :end for 